\title{
New ways into the Sami language
}

\author{
KAJSA KUOLJOK
}

\begin{abstract}
The Sami language is the carrier of our Sami heritage, and could itself act as a key that opens the door to our wider understanding of it. During the period 2012-14, Átte Museum in Jokkmokk, Sweden, worked on the language project Giela muitalusat / Giela giehto. The Sami Language - Three Generations Tell ${ }^{1}$, with the aim of collecting the different generations' thoughts and ideas about the Sami language. Sami cultural heritage is not only about traditions of the past; it is also contemporary and urban. Many young Sami alternate between joining in with traditional Sami activities and being part of modern society. Ajtte Museum has aimed to set the focus on young Sami people, through various projects, and to try to identify issues that are relevant to the younger generation. The general image of Sami culture and life as reflected in museums today must be extended, so that more people will recognise that they themselves are an integral part of it. In the project, using film and still photography, young people documented and presented their everyday life and thoughts on how the use of the Sami language and Sami culture could be developed in the local community today.
\end{abstract}

Keywords: Sami language, museums and youth, traditional Sami knowledge, intangible heritage, urban vocabulary.

Ájtte, the Swedish Mountain and Sami Museum, is located north of the Arctic Circle in Jokkmokk. Situated in the Swedish part of Sápmi, Ájtte Museum is the country's largest museum of Sami culture. From the standpoint of the indigenous people, the Museum is immensely important; it is a cultural institution where the Sami people themselves tell their own story.

The exhibitions of the Museum cover both the tangible and the intangible cultural heritage of the Sami people. Arbbediehto is part of the intangible cultural heritage; this is the Lule
Sami word for Sami traditional knowledge. Árbbediehto is the sum total of all knowledge that the Sami people have accumulated over thousands of years of traditional hunting and gathering (Utsi 2007), including modern traditions (Nordin 2010). The Sami language maintains our Sami cultural heritage and it may also function as an important key to understanding of culture (Guttorm 2011). In 2011, Sweden ratified the Unesco Convention for the Safeguarding of the Intangible Cultural Heritage (2003). ${ }^{2}$ The purpose of the convention is to encourage respect for the great 
significance of our intangible cultural heritage. The protection (i.e. safeguarding) mentioned in the convention concerns identification, documentation, preservation, renewal, and promotion of our intangible cultural heritage in order to keep it alive and give it new energy.

\section{The Sami language in the SPOTlight}

Many studies have shown that young people are very proud of their Sami culture and identity, feeling confident in Sami environments. The Sami language is especially recognised as an important factor in building up their confidence. However, studies have also shown that young people feel that there is great ignorance concerning the Sami people, and that prejudice and stereotype images in the media do not reflect the reality of today's youth. ${ }^{3}$ There is a lack of knowledge about the urban, modern environments in which many young Sami grow up today, and consequently also a lack of a corresponding language.

With these considerations in mind, a project named Giela muitalusat/Giela giehto. The Sami Language - Three Generations Tell was created in which the museum tried to find new ways of collecting information about young people's lives, thoughts, and language (Kuoljok 2014). People of different ages, from seven to seventy years old, were contacted for interviews. With young people between the ages of seven and fifteen, we had group discussions in cafés or restaurants, eating and relaxing, to have meaningful discourse about the language. With the adults, we conducted both group sessions and individual interviews. A seminar, Collaborating to Revitalize Indigenous Language and Culture, was arranged where pupils and teachers gathered for an open discussion about needs and visions regarding the future of the language. More than a hundred
Sami people of different ages participated in these activities. The idea behind involving three generations was that all thoughts and viewpoints were important to consider, although we concentrated mainly on the views of young people. The Museum had realised that the thoughts of Sami children and young people about Sami language and culture were not properly represented in the research and documentation at the Museum. Children and young people were seldom actively involved in the work of the Museum. This led to the idea that young people should be given the opportunity to stand up and state their opinions, and that the Museum should try to support this by being more cooperative and interactive - so that the younger generation would be more active in working with (and for) the Sami language.

\section{YOUNG PEOPLE'S VIEWS REGARDING PLACES}

During this first part of the project - the interviews - it became clear that young people did not think that they, as users of the language, were being seen or heard in public places. For a long time, the Sami language has been conspicuously absent from public contexts. Our daily life today is centred around towns and cities, and using, for example, signs in Sami in public environments was considered to be a simple way of making space for the Sami language, at the same time sending out the message that it is of relevance to society.

Consequently, in the second part of the project we tried to obtain an idea of what activities, arenas, and places are used by these young people and where they would want the Sami language to be heard and experienced to a greater extent. This was achieved through cooperation with school pupils aged ten to 
sixteen. The method was to involve language reconnaissance scouts; boys and girls made a survey of the local community with still cameras and video cameras. Using these tools, these young people made a picture and video account of their everyday life in school, at home, and during their spare-time activities. The main emphasis of the study was to identify the places where young people felt that there was a lack of Sami language. They pointed out public places in the community, at school, and in the sports hall, the ice-skating ring, the sports shop, and the grocery shop where there were no signs in Sami language. In their survey, they also specified certain products, such as computer games.

With their survey, the young people directed attention to the language they encounter in their everyday life. The language reconnaissance showed many possibilities and failings of our society today regarding the Sami language. A greater number of public institutions and companies should take responsibility and participate in making the Sami language visible more than they do today.

\section{MAKING THE LANGUAGE VISIBLE}

The third part of the language project focused on practical work. Graffiti workshops were arranged where classes 5 and 6 (with children aged 11-13) from the Sami school in Jokkmokk could sketch, draw, and paint graffiti with Sami text (fig. 1-2). The children were encouraged to express themselves in writing in the Sami language, the point being that it should be fun and enjoyable to work with the language. The work was done partly on museum premises and partly in the woods nearby. The artwork gave these young people the tools to be able to recount their everyday life.

Many young Sami alternate between joining in with traditional Sami activities and being part of modern society (Jannok Nutti 2011). The young people have a need for a wider Sami vocabulary, with words that have to do with the things they do in their spare time: playing football or hockey, doing gymnastics, or horseback riding. They want to be able to use slang words and modern words even in the Sami language. Some of the words they wanted translations for were "snow-mobile rules", "top model" and "cool". In the practical workshops, a teacher said that the thought of working with new Sami words had not occurred to the teachers before, and that it was difficult to work out new words and phrases. All the same, the teacher mentioned the importance of Sami, not only as a language used in the Sami tent or in the reindeer woods. Since árbbediehto Sami traditional knowledge - includes modern traditions, the Sami language must have modern words in order to support the Sami culture today. It is essential to follow current events in modern society and to try to find new phrases in Sami, because they are sorely needed. Old practices should be challenged to create new knowledge and to generate new information. This should start from the inside, in order to identify basic ideas and to find out how it can be transformed to fit today's society. "Some modern words are significant, like 'cool', which does not exist in Lule Sami, but now language experts have been working on it, since we asked" (teacher; my translation).

Sami society needs to keep up with the rest of society, and there is a constant demand for new Sami words. It can be difficult to produce new words. According to Nils Jernsletten (2002), it is also a challenge to induce Sami society to use these words. Lennart Åstot describes the changing language as part of the changing Sami life: "Sámi language has suffered from the way we live today. You can try to save the 
language with modern tools, but it is very hard" (Åstot 2013:79-80).

\section{“Us" AND “THEM"}

One aspect that emerged in the interviews and the practical work was that the language strengthened the feeling of belonging to the group, creating a difference between "us" and "them", Sami-speaking people and non-Samispeaking people. This occurs through hardly noticeable allusions, by using linguistic signals that are obvious to the initiated but completely incomprehensible to those who are "out of it". Written text can be formulated in such a way that it is misleading. To be able to discern what is meant, it is necessary to be among the initiated. These small considerations of "not making sense" are indicative of how young people perceive the local community - of how the language emphasises their group feeling and how they use the language to send undercover messages to those who understand it. Ájtte Museum works from an insider's standpoint, knowing the Sami culture and knowing the language. Without this knowledge, it would be difficult to detect these allusions. Something that did not emerge in the interviews, but that was seen in the practical activities, was how current events can be regarded in the local community. T-shirts with printed messages and sprayed texts in Sami saying "Get out" and "Give it back" were a response to the local mining debate, where many have been opposed to companies that might start up mining in the area. ${ }^{4}$

\section{SignS AND SIgNIFICANCE}

The project showed some possibilities and some failings concerning the Sami language, and we wanted more people to know about these matters. It was therefore essential to give the

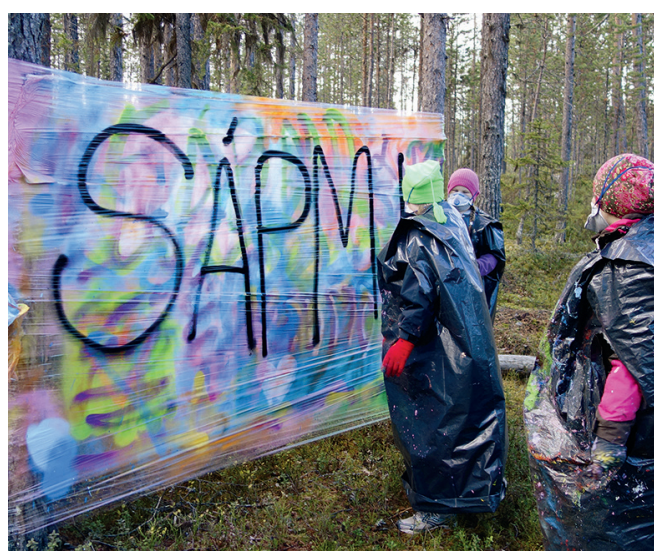

Fig. 1-2. Graffiti workshops with children from the Sami school in Jokkmokk, 2013. Photos: Kajsa Kuoljok.

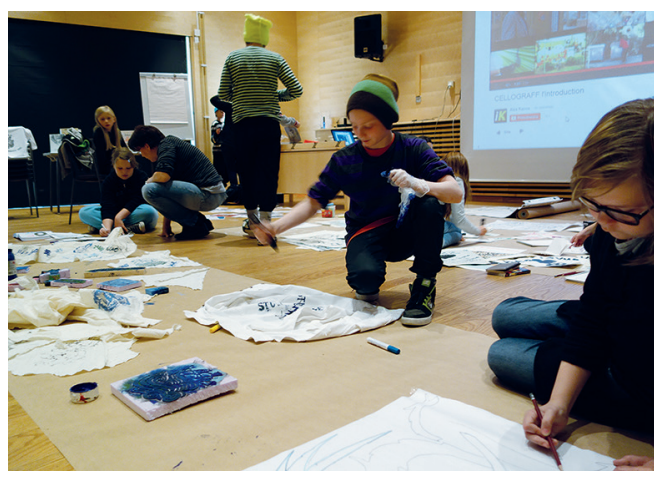

relevant parts of the local community feedback from the project. In the local context, this was achieved through lectures and exhibitions; for a broader public, we could use the website www.giella.se, Facebook, and Instagram. The young language surveyors pointed out places where they would like signs in Sami; this was then followed up by a visit from the Museum to convey the message to those concerned. The Museum talked to headmasters at various schools, managers, shopkeepers, and owners of restaurants and businesses in order to inform 
112 them of the suggestions made by the young people. Many of those we visited said that the thought had never struck them, since nobody had ever asked for Sami signs. Practical and financial obstacles were mentioned as reasons for why they had never used signs in Sami before. The fact that there is a lack of knowledge as to what matters minority groups have a right to ask for is shown in Nationella minoriteter. Rapport om tillämpningen av lagen om nationella minoriteter och minoritetsspråk år 2012 (2013) (Report concerning the application of the law concerning national minorities and minority languages; my translation), published by the County Administration Board (Länsstyrelsen) in Stockholm, together with the Sami Parliament (Sametinget). There is a limited understanding and awareness of the requirements and conditions of the national minorities concerning a wide range of questions, because there is no structured system for assessment.

In order to increase awareness in the local community about the thoughts and suggestions that were communicated to us by the young people, a book was produced: Samisk skyltning: Att synliggöra det samiska $i$ vardagen (Kuoljok 2014), (Sami signage making the Sami language visible in everyday life; my translation). The idea was that it should act as a link to the local community. Through visits and by distributing the book, the project has strived to be a local influence that might eventually change the situation in the local community. Another result of the project was that posters and ready-made signs were produced in Lule Sami, South Sami, and North Sami. These were made to suit public institutions and also for use at home, since many had answered that they did not have the financial means or the knowledge required to produce such translations.

\section{THE MUSEUM - A RESOURCE IN SOCIETY}

Ájtte Museum is a vital part of Sami society, with its work in strengthening the Sami identity and towards further development of the Sami culture. An important task for the Museum is to illustrate modern Sami life, so that more people recognise themselves in this context. By focusing on the Sami language and by doing as the young language surveyors did, searching the community through a "language lens", looking for the presence of the Sami language, it becomes obvious just how invisible the Sami language is in our modern society. The Sami language is regarded as a crucial resource in Sami society, and the project has also worked towards promoting it in society as a whole. The most important result of the language project is that the Museum has created good relations with young Sami people throughout the local community. In this way, the Museum had a cooperative role rather than acting as an institution; together with the young people, we worked with issues that were relevant to them. In interviews and also with their own photographs and films, they have told us about the Sami language and about their lives today. Along with the things that they produced, this material will be kept at the Museum for posterity. It reflects both individuals and the entire community. It is culture made by - and intended for - young people.

\section{Notes}

1. Giela muitalusat / Giela giehto is North and Lule Sami for "the language tells".

2. http://unesdoc.unesco.org/ images/0013/001325/132540e.pdf

3. Rätten till delaktighet och inflytande för samiska barn och ungdomar 2008; Jannok Nutti 2011.

4. E.g. "Samisk kamp för kulturell överlevnad", 
thematic issue of the journal Kulturella Perspektiv 2014:1.

\section{LITERATURE}

Åstot, Lennart 2013. "Sami language and culture." In Tero Mustonen \& Eija Syrjamaki (eds.). It is the Sami who Own this Land. Sacred Landscapes and Oral Histories of the Jokkmokk Sami. Vaasa, Finland: Snowchange Cooperative.

Convention for the Safeguarding of the Intangible Cultural Heritage, 2003. Paris: Unesco http://unesdoc.unesco.org/ images/0013/001325/132540e.pdf

Guttorm, Gunvor 2011. "Árbediehtu (Sami traditional knowledge) - as a concept and in practice." In Jelena Porsanger \& Gunvor Guttorm (eds.). Working with Traditional Knowledge. Communities, Institutions, Information Systems, Law and Ethics. Writings from the Árbediehtu Pilot Project on Documentation and Protection of Sami Traditional Knowledge. Guovdageaidnu: Sami allaskuvla, 59-76.

Jannok Nutti, Ylva (ed.) 2011. Att vara ung: Mellan cafébesök och traditionella kunskaper. Projektrapport $=$ To be young: Between café visits and traditional knowledge. Project report. Jokkmokk: Ájtte.

Jernsletten Nils 2002. "Samisk språk i dagens samfunn - behov och muligheter." I Endre Mørck \& Tuomas Magga (eds.). Samiska i ett nytt årtusende. København: Nordiska ministerrådet.

Kulturella Perspektiv 2014:1.
Kuoljok, Kajsa 2013. Árrangátten $=$ Árrangáttis $=$ Vid eldstaden. Idag, igår och i framtiden. Jokkmokk: Ájtte, Svenskt fjäll- och samemuseum.

Kuoljok, Kajsa 2014. Samisk skyltning: Att synliggöra det samiska i vardagen. Jokkmokk: Ájtte, Svenskt fäll- och samemuseum. http://www.ajtte.com/wpcontent/uploads/2009/05/Samisk-skyltning.pdf

Nationella minoriteter. Rapport om tillämpningen av lagen om nationella minoriteter och minoritetsspråk år 2012. 2013. Stockholm: Länsstyrelsen i Stockholms län.

Nordin, Åsa (ed.) 2010. Árbediehtu: Samiskt kulturarv och traditionell kunskap. Kiruna: Sametinget.

Rätten till delaktighet och inflytande för samiska barn och ungdomar. Ett samarbetsprojekt mellan Barnombudsmannen i Finland, Barneombudet $i$ Norge och Barnombudsmannen i Sverige. 2008. Stockholm: Barnombudsmannen.

Utsi, Per Mikael 2007. Traditionell kunskap och sedvänjor inom den samiska kulturen: Relaterat till bevarande och hållbart nyttjande av biologisk mångfald. Kiruna: Sametinget. http://www. sametinget.se/2426

Kajsa Kuoljok, Curator

kajsa.kuoljok@ajtte.com

Ájtte, Svenskt fjäll- och samemuseum

Box 116

SE-962 23 Jokkmokk, Sweden 